\title{
Does Foreign Aid Increase Foreign Direct Investment?
}

Selaya, Pablo; Sunesen, Eva Rytter

Publication date:

2008

Document version

Publisher's PDF, also known as Version of record

Citation for published version (APA):

Selaya, P., \& Sunesen, E. R. (2008). Does Foreign Aid Increase Foreign Direct Investment? Department of Economics, University of Copenhagen. 


\section{Discussion Papers Department of Economics University of Copenhagen}

$$
\text { No. } 08-04
$$

Does Foreign Aid Increase

Foreign Direct Investment?

Pablo Selaya and Eva R. Sunesen

Studiestræde 6, DK-1455 Copenhagen K., Denmark

Tel. : +4535323082 - Fax: +4535323000

http://www.econ.ku.dk

ISSN: 1601-2461 (online) 


\title{
DOES FOREIGN AID INCREASE FOREIGN DIRECT INVESTMENT?*
}

\author{
Pablo Selaya and Eva R. Sunesen ${ }^{\dagger}$ \\ 5 February 2008
}

\begin{abstract}
The notion that foreign aid and foreign direct investment (FDI) are complementary sources of capital is conventional among governments and international cooperation agencies. This paper argues that the notion is incomplete. Within the framework of an open economy Solow model we show that the theoretical relationship between foreign aid and FDI is indeterminate. Aid may raise the marginal productivity of capital by financing complementary inputs, such as public infrastructure projects and human capital investment. However, aid may also crowd out productive private investments if it comes in the shape of physical capital transfers. We therefore turn to an empirical analysis of the relationship between FDI and disaggregated aid flows. Our results strongly support the hypotheses that aid invested in complementary inputs draws in foreign capital while aid invested in physical capital crowds out FDI. The combined effect of these two types of aid is small but on average positive.
\end{abstract}

Keywords: Foreign aid, foreign direct investment (FDI), open economy Solow model.

JEL classifications: F21, F35, H40, O19.

\section{Introduction}

A salient point in the UN (2002) Monterrey Report of the International Conference on Financing for Development is that official development assistance (ODA), trade and foreign direct investment (FDI) are three essential tools for development financing. In particular:

${ }^{*}$ We are grateful for comments from Carl-Johan Dalgaard, Heino Bohn Nielsen, Finn Tarp, Thomas Rønde, Thomas Barnebeck Andersen and Nina Blöndal, as well as from participants at the DGPE 2007 workshop in Sandbjerg and the Nordic Conference in Development Economics 2007 in Copenhagen.

${ }^{\dagger}$ Department of Economics, University of Copenhagen. Studiestræde 6, 1455 Copenhagen K, Denmark. E-mail addresses: pablo.selaya@econ.ku.dk and eva.rytter.sunesen@econ.ku.dk. 
"ODA plays an essential role as a complement to other sources of financing for development, especially in those countries with the least capacity to attract private direct investment. A central challenge, therefore, is to create the necessary domestic and international conditions to facilitate direct investment flows, conducive to achieving national development priorities, to developing countries, particularly Africa, least developed countries, small island developing States, and landlocked developing countries, and also to countries with economies in transition." (UN, 2002, p. 9).

However, the implicit presumption that ODA has a "catalysing" effect on FDI, i.e., that aid and FDI are complements, is by no means evident. Kosack and Tobin (2006) argue that aid and FDI are unrelated, because aid is mainly oriented to support the government budget and finance investments in human capital, while FDI is a private sector decision and relatively more connected to physical capital. Caselli and Feyrer (2007) find that the marginal product of capital (MPK) is roughly the same across countries, and one of the implications is that increasing aid inflows to developing countries will lower the MPK in these economies and will tend to be fully offset by outflows of other types of capital investments (p. 540). If this is the case, aid and FDI are clearly closer to being substitutes rather than being complements.

This paper provides a unified framework for assessing the relative merit of these different claims. We set up an open-economy Solow model with perfect capital mobility that distinguishes between aid directed towards complementary factors of production and aid invested in physical capital. The distinction serves to illustrate, on the one hand, that aid invested in complementary factors increases MPK in the recipient country, which tends to draw in additional foreign resources, and thus helps to sustain a higher level of capital over time. For example, aid can ease important bottlenecks in poor countries by financing public infrastructure and human capital investments that would not have been undertaken private actors (due to the free-riding problem in financing public goods), nor by public agents (because of the budgetary constraints that prevent aid-recipient governments from undertaking this type of investments). On the other hand, the model also shows that foreign aid invested in physical capital directly competes with other types of capital, and thus replaces investments that private actors would have undertaken anyway. In this case, capital mobility and rate-of-return equalisation across countries will give rise to a flight of other types of capital after an aid flow has been received.

The theoretical model provides a number of results and testable predictions. First, for a given level of domestic saving, aid invested in physical capital crowds out other types of foreign investments in physical capital, one for one. Second, aid invested in complementary factors of production has an ambiguous effect on FDI. The logic of the ambiguity is that, while an increase in complementary factors increases MPK, the productivity increase also raises income, domestic savings and domestic investments, which tends to lower MPK 
and thus to crowd out foreign investments. These two findings suggest that the overall impact of aid on FDI is ambiguous and that the composition of aid matters. Finally, the relationship between complementary aid and FDI is unlikely to be linear, so scale effects from this type of aid should be taken into account.

We take the implications of our theoretical model to the data utilising a panel of 84 countries over the period 1970-2001. We find a large and positive effect of aid invested in complementary factors, while aid invested in physical capital has a negative impact on FDI. Although the combined impact of these two types of aid on FDI remains positive, our results imply that more aid should be directed towards inputs complementary to physical capital to optimise the return on aid. The results are robust to (1) a broader definition of complementary aid than that adopted in our benchmark estimations, (2) to allowing for imperfect capital mobility, and (3) to including other traditional FDI determinants.

The paper is structured as follows. Section 2 reviews the scarce empirical literature on FDI and aid. Section 3 introduces the theoretical model of FDI and aid building on an open economy Solow model with perfect capital mobility. Section 4 discusses relevant econometric issues and presents the data. Section 5 shows the results, and Section 6 tests their robustness. Section 7 sums up and discusses policy implications.

\section{Literature Review}

The relationship between aid and FDI is controversial and empirical results remain inconclusive. To our knowledge, only four papers explicitly analyse the relationship between aid and FDI. Harms and Lutz (2006) and Karakaplan et al. (2005) analyse the question for a broad sample of developing countries. Karakaplan et al. (2005) find that aid has a negative direct effect on FDI and that both good governance and financial market development significantly improve the impact of aid on subsequent flows of FDI. Harms and Lutz (2006), on the other hand, find that once they control for the regulatory burden in the host country, aid works as a complement to FDI and, surprisingly, that the catalysing effect of foreign aid is stronger in countries that are characterised by an unfavourable institutional environment.

The two case studies based on Japanese FDI and aid flows in Kimura and Todo (2007) and Blaise (2005) also find incongruent results. While Blaise (2005) finds positive effects of aid to infrastructure projects, Kimura and Todo (2007) find no positive infrastructure effect, no negative rent-seeking effect but a positive vanguard effect (arising when foreign aid from a particular donor country promotes FDI from the same country but not from other countries).

This paper argues that the mixed results can be explained by the high level of aggregation of the aid variable. While Karakaplan et al. (2005) include only overall ODA, Harms and Lutz (2006) also distinguish between grants, technical cooperation grants, as 
well as bilateral and multilateral aid. However, it remains unclear why one would expect foreign investors to react differently to these sources of aid. Kimura and Todo (2007) apply the idea of different types of aid, but construct their proxies relying only on data for aid commitments and they only separate out aid to physical infrastructure.

\section{A Theoretical Model of FDI and Aid}

A general shortcoming in the empirical literature is the lack of consensus on the specification of the FDI relation, and none of the existing empirical papers on aid and FDI are supported by a theoretical model. This paper closes this gap by proposing a Solow model for a small open economy to model the main characteristics of the relationship between aid and FDI. ${ }^{1}$

We assume a Cobb-Douglas production function where GDP per capita, $y$, is given by

$$
y=A k^{\alpha}
$$

where $k$ is the stock of physical capital per capita, $\frac{K}{L}, \alpha$ is a constant and $A$ denotes total factor productivity.

We assume that the total flow of foreign aid, $A I D$, can be split into aid invested in complementary factors, $A I D_{A}$, and aid invested in physical capital, $A I D_{K}$, where $A I D=$ $A I D_{A}+A I D_{K} \cdot A I D_{A}$ by nature raises the marginal productivity of all production factors that are complementary to physical capital. ${ }^{2}$ For example, infrastructure investments lead to the interconnection of markets (Easterly and Levine, 1999), while investments in human capital improve technology adoption. $A I D_{K}$, on the other hand, enters the production function only through its effect on physical capital accumulation, and has no (augmenting) effect on total factor productivity. ${ }^{3}$

To model this explicitly, we first assume that complementary aid has an augmenting effect on all production factors that are complementary to physical capital, and we thus allow the flow of $A I D_{A}$ to increase the existing stock $\left(A_{0}\right)$ of $A$ in the economy:

$$
A=A_{0}+A I D_{A}
$$

Allowing complementary aid to have a direct impact on $A$ is a shorthand for the idea that $A I D_{A}$ has an augmenting effect on any production factor other than $k$ (e.g. human capital,

\footnotetext{
${ }^{1}$ One exception is Beladi and Oladi (2007) who analyse the question in a general equilibrium setting where all foreign aid is used to finance public goods.

${ }^{2}$ The argument of complementarity between public and private investment is generalised by Clarida (1993) and Chatterjee et al. (2003). Reinikka and Svensson (2002) find empirical support for the importance of complementary public capital for foreign investors.

${ }^{3}$ We thus allow part of foreign aid to be productivity enhancing while FDI brings no spillovers. In reality, all capital transfers might contain some knowledge transfer but the assumption is made to keep the model simple and tractable.
} 
public investments, new technology, etc.) and, thus, it is able to increase -ultimatelythe MPK.

Second, we assume an open economy. ${ }^{4}$ Accordingly, in per capita terms, capital equipment can be financed by (i) domestic savings ( $S=s y$, where $s$ is a given savings rate), (ii) foreign direct investments $(f d i)$ and (iii) the inflow of aid invested in physical capital $\left(\operatorname{aid}_{K}\right)$. Then capital accumulation per capita is given by

$$
\dot{k}=s y+f d i+\operatorname{aid}_{K}-(n+\delta) k
$$

where $n$ is the population growth rate and $\delta$ is a fixed depreciation rate.

With perfect capital mobility, the world real rate of return, $r^{w}$, pins down at any point in time the net return to capital $(\mathrm{MPK}-\delta)$, and thus

$$
r^{w}=\mathrm{MPK}-\delta=A \alpha k^{\alpha-1}-\delta .
$$

According to (4), the steady state level of $k$ at any point in time is given by

$$
k^{*}=\left[\frac{A \alpha}{r}\right]^{\frac{1}{1-\alpha}}
$$

where $r$ is defined as a gross world real rate of return, $r^{w}+\delta$.

Rewriting (3) taking (5) as given, the flow of FDI per capita is determined as the residual

$$
f d i=-a i d_{K}-s y^{*}+(n+\delta) k^{*}
$$

where $y^{*}=A k^{* \alpha}$.

At a first glance, (6) seems to support the Caselli and Feyrer (2007) conjecture that aid and FDI are substitutes: for a given level of domestic savings, equalisation between MPK and $r$ requires an increase in foreign aid to be accommodated by a proportional reduction in FDI:

$$
\frac{\partial f d i}{\partial a i d_{K}}=-1
$$

However, this finding only holds for aid invested in physical capital. The effect of complementary aid, on the other hand, has two components:

$$
\frac{\partial f d i}{\partial a i d_{A}}=-s \frac{\partial y^{*}}{\partial a i d_{A}}+(n+\delta) \frac{\partial k^{*}}{\partial a i d_{A}} .
$$

First, since

$$
s \frac{\partial y^{*}}{\partial a i d_{A}}=s \frac{\partial\left(A k^{* \alpha}\right)}{\partial a i d_{A}}=s\left[L k^{* \alpha}+A \alpha k^{* \alpha-1} \frac{\partial k^{*}}{\partial a i d_{A}}\right]>0,
$$

\footnotetext{
${ }^{4}$ In line with Sørensen and Witta-Jacobsen (2006, Ch. 4) and Turnovsky (2000).
} 
complementary aid has a positive effect on domestic savings and thus on domestically financed capital investments. This result comes from the fact that aid $_{A}$ shifts the production function thereby raising the steady state levels of income and domestic savings. Given the assumption of MPK equalisation in (4), the corresponding increase in domestically financed investments causes a proportional reduction in the need for FDI of the size $-s \frac{\partial y^{*}}{\partial a d_{A}}$.

Also, since

$$
\frac{\partial k^{*}}{\partial \operatorname{aid}_{A}}=\frac{\partial}{\partial a i d_{A}}\left(\left[\frac{A \alpha}{r}\right]^{\frac{1}{1-\alpha}}\right)=\frac{1}{1-\alpha}\left[\frac{A \alpha}{r}\right]^{\frac{\alpha}{1-\alpha}} \frac{L \alpha}{r}>0
$$

we see that complementary aid has a positive effect on the steady state capital stock. This finding is based on the augmenting effect of aid $_{A}$, which raises MPK and thus allows the recipient country to increase its capital stock without experiencing a counterbalancing capital flight. That is, for a fixed $s$, aid-financed investments in complementary factors allow a sustainable increase in FDI equal to $(n+\delta) \frac{\partial k^{*}}{\partial a i d_{A}}$.

This model holds then several implications that should be taken into account when assessing the empirical relationship between aid and FDI. First, the effect of total aid on FDI is ambiguous:

$$
\frac{\partial f d i}{\partial a i d}=\frac{\partial f d i}{\partial a i d_{K}}+\frac{\partial f d i}{\partial a i d_{A}}=-1-s \frac{\partial y^{*}}{\partial a i d_{A}}+(n+\delta) \frac{\partial k^{*}}{\partial a i d_{A}} \gtrless 0,
$$

because we expect aid to production sectors to have a negative effect on FDI, but the effect of complementary aid is indeterminate. Second, from equations (9) and (10), since the marginal effect of complementary aid on FDI includes the level of aid itself, the relationship between complementary aid and FDI is not linear. In particular, there are scale effects from complementary aid that should be taken into account. Since $-s \frac{\partial y^{*}}{\partial a d_{A}}$ and $(n+\delta) \frac{\partial k^{*}}{\partial a_{i} d_{A}}$ work in opposite directions, the sign of the second order effects will also be indeterminate and will need to be assessed empirically. Third, the model stresses the need to take all sources of capital into account, and it is therefore essential to include domestic savings as an additional explanatory variable in the empirical FDI analysis. To our knowledge, this has not been done before.

\section{Econometric Issues}

In a panel setting, the econometric interpretation of the aid-FDI relationship is

$$
f d i_{i t}=\beta_{0}+\beta_{1} A_{i t}^{0}+\beta_{2} n_{i t}+\beta_{3} S_{i t}+\beta_{4} a i d_{i t}^{K}+\beta_{5} a i d_{i t}^{A}+\beta_{6}\left(a i d_{i t}^{A}\right)^{2}+u_{i t},
$$


where $f d i_{i t}$ is FDI per capita in country $i$ during period $t, A_{i t}^{0}$ is the overall productivity level at the beginning of period $t, n_{i t}$ is population growth, $S_{i t}$ is domestic savings per capita, $\operatorname{aid}_{i t}^{K}$ is aid invested in physical capital, and $a i d_{i t}^{A}$ is aid invested in complementary factors. The square of aid $_{i t}^{A}$ is included in (12) to control for the scale effects of complementary aid.

We expect $\beta_{1}$ to be positive since a high productivity level gives a high steady state level of capital, $\beta_{2}$ should be positive since a fast growing population lowers the per capita capital stock and thus allows for an increase in FDI per capita, and $\beta_{3}$ should be negative since high domestic saving lowers the need for foreign capital. From equation (7) we know that aid $_{K}$ crowds out foreign investments one-to-one, $\beta_{4}=-1$, whereas the effect of aid $_{A}$ $\left(\beta_{5}\right.$ and $\left.\beta_{6}\right)$ is indeterminate. Since data on total productivity is unavailable, the next section will discuss the strategy used to identify $A_{i t}^{0}$ empirically.

\subsection{Productivity}

Since data on the initial productivity level $\left(A_{i t}^{0}\right)$ is unavailable, we need to find valid proxies. In the first case, we use pooled OLS (POLS) and estimate

$$
f d i_{i t}=\alpha_{t}+\beta_{0}+\beta_{1} n_{i t}+\beta_{2} S_{i t}+\beta_{3} a i d_{i t}^{K}+\beta_{4} a i d_{i t}^{A}+\beta_{5}\left(a i d_{i t}^{A}\right)^{2}+u_{i t},
$$

where $\alpha_{t}$ is a time-specific constant that captures common productivity shocks at time $t$. However, not all countries start out with the same initial conditions and we thus allow also for cross sectional differences in productivity by including time-invariant country-specific fixed effects, $\alpha_{i}$,

$$
f d i_{i t}=\alpha_{t}+\alpha_{i}+\beta_{0}+\beta_{1} n_{i t}+\beta_{2} S_{i t}+\beta_{3} a i d_{i t}^{K}+\beta_{4} a i d_{i t}^{A}+\beta_{5}\left(a i d_{i t}^{A}\right)^{2}+u_{i t}
$$

This equation can be estimated consistently and efficiently with a fixed effects model (FE). However, if productivity evolves unequally across countries over time, regression (14) leaves out important information. We therefore extend the list of variables to include a lagged dependent variable, which captures time-moving country-specific factors as well as agglomeration effects,

$$
f d i_{i t}=\alpha_{t}+\alpha_{i}+\beta_{0}+\beta_{1} f d i_{i t-1}+\beta_{2} n_{i t}+\beta_{3} S_{i t}+\beta_{4} a i d_{i t}^{K}+\beta_{5} a i d_{i t}^{A}+\beta_{6}\left(a i d_{i t}^{A}\right)^{2}+u_{i t}
$$

Equation (15) can be estimated consistently and efficiently using the Arellano and Bond (1991) Generalised Method of Moments (GMM) estimator. It is important to notice that including a lagged dependent variable also reduces the need to control for other FDI determinants. All estimators use standard errors that are robust to arbitrary heteroskedasticity as well as intra-group correlation (clustering). 


\subsection{Endogeneity}

We need to consider the possible endogeneity of aid in estimating the above equations, since all estimators are consistent only if all explanatory variables are exogenous. Aid would be endogenous, for example, if donors systematically disburse more resources to those countries that are neglected by private foreign investors (Harms and Lutz, 2006). We therefore estimate (13)-(15) following the instrumentation strategy in Hansen and Tarp (2000, 2001), Dalgaard and Hansen (2001) and Dalgaard et al. (2004).

The first set of instruments accounts for donors' overall preference for granting more aid to countries with smaller populations and lower levels of income per capita and thus includes (lagged) interactions between levels of aid and (i) the size of population and (ii) the initial level of GDP per capita in the recipient country. We also include the lagged level of aid to account for persistency in other determinants of aid as well as a dummy variable for African countries in the CFA franc zone to capture particular donors' strategic interests.

Tests confirm the validity of our instruments, and the Durbin-Wu-Hausman test finds that the aid variables should be treated as endogenous in the FDI relation. All the results reported in the next section are therefore based on Instrumental Variables (IV) methods.

\subsection{Data}

The dependent variable, $f d i_{i t}$, is net FDI inflows in constant US dollars from the UNCTAD Foreign Direct Investment database, divided by the population to control for country size. The main explanatory variables are the population growth rate and savings per capita from the WDI (2005).

The aid variables are based on total net flows of official aid disbursements reported in the OECD/DAC database. Since data on sectoral disbursements are available only after 1990, the measure of per capita aid flows to sector $s$, aid $d_{i t}^{s}$, is constructed using sectoral commitments as a proxy for sectoral disbursements. In particular, we follow Clemens et al. (2004) and Thiele et al. (2006) and assume that the proportion of aid actually disbursed to sector $s$ is equal to the proportion of aid committed to sector $s$, and hence that

$$
a i d_{i t}^{s} \approx \frac{\text { commit }_{i t}^{s}}{\sum_{s} \text { commit }_{i t}^{s}} \sum_{s} a i d_{i t}^{s}
$$

where commit $t_{i t}$ is the amount of ODA commitments to sector $s$. Approximating sectoral disbursements with sectoral commitments may cause some concerns due to differences in definitions and statistical record (see Clemens et al., 2004, for more details). However, according to Odedokun (2003) and Clemens et al. (2004) this problem is likely to be small since disbursements and commitments (both on the aggregate and sectoral levels) are highly correlated. Also, annual discrepancies are likely to be larger than averages, 
and we thus average the data over five-year intervals.

Aid is decomposed into two broad categories according to its purpose of investment:

- Aid invested in complementary inputs: aid oriented to social infrastructure (such as education, health, and water supply projects) and economic infrastructure (such as energy, transportation and communications projects).

- Aid invested in physical capital: contributions to directly productive sectors (such as agriculture, manufacturing, trade, banking and tourism projects).

These two aid categories capture the main characteristics of aid $_{A}$ and aid $_{K}$ : aid invested in complementary factors is intended to generate positive spillover effects (public goods, inputs complementary to physical capital) whereas aid invested in physical capital has a more narrow purpose and could more easily have been undertaken by private investors. Other sectoral aid categories (like multisector support, programme assistance, debt reorganisation, emergency assistance and unallocated types of aid) are excluded from the analysis since they are primarily oriented to provide fiscal budget support in the recipient country. ${ }^{5}$

\section{Results}

Figure 1 in Appendix shows the partial correlation between FDI and aid invested in physical capital. While there seems to be a negative relationship between the two variables, it is difficult to assess if there is full crowding out from the downwards sloping line (that is, to assess if the slope is -1 ). Figure 2 in Appendix depicts the partial correlation between FDI and aid invested in complementary goods. The figure clearly indicates that the two variables are positively correlated and that the relationship might not be linear. However, the exact predictions from the theoretical model can only be tested in a more comprehensive framework where country-specific characteristics capture the cross-sectional heteroskedasticity clearly prevalent in the figures.

Results from estimating equations (13)-(15) for a sample of 84 countries using fiveyear intervals are reported in Table 1. Independently of the chosen estimator, our results strongly support the notion that aid invested in complementary factors has a catalysing effect on FDI. This means that the short-run replacement effect of aid $_{A}$ on FDI is outweighed by the positive effect that complementary aid has on the long-run levels of income and capital per capita. A Hausman test confirms the significance of fixed effects, and the highly significant lagged dependent variable suggests that we should rely on the consistent

\footnotetext{
${ }^{5}$ Section 6 includes a test for robusteness of the results with respect to the definition of complementary aid, and a note about the changes in the results when variables possibly correlated with aid $_{A}$ are included in the regressions.
} 
Table 1: FDI and Foreign Aid

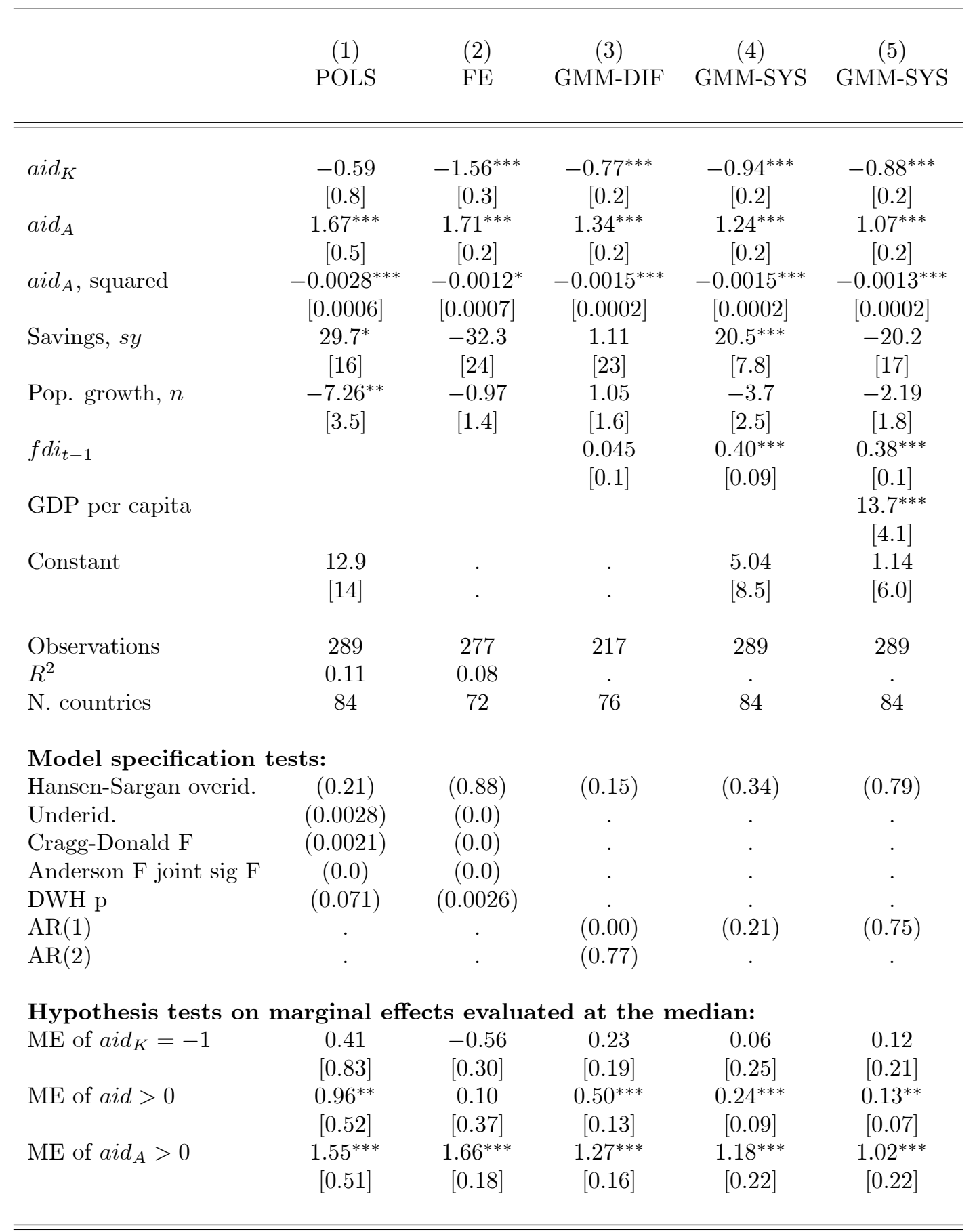

Notes. ${ }^{* * *} \mathrm{p}<0.01,{ }^{* *} \mathrm{p}<0.05,{ }^{*} \mathrm{p}<0.1$. Robust standard errors in brackets, p-values in parentheses. The dependent variable is FDI per capita. All regressions include time dummies. Aid variables are instrumented with own lags, interactions with GDP per capita, $\log ($ pop) and a FRZ dummy. 
and efficient Arellano and Bond (1991) GMM estimator in our further analysis. When the time series are persistent, the first-difference GMM (GMM-DIF) estimator is poorly behaved since under such conditions lagged levels of the variables are only weak instruments for subsequent first-differences. We therefore rely on the system GMM (GMM-SYS) estimator suggested by Arellano and Bover (1995) and Blundell and Bond (1998). All variables are treated as endogenous, which means that instruments should be lagged two periods or more to be valid.

The results in column (4) in Table 1 show that, for a given domestic savings rate, one aid dollar invested in complementary factors draws in 1.24 dollars of FDI, both in per capita terms. The square of complementary aid is negative and significant, suggesting that the "savings" effect described in equation (9) dominates for sufficiently high levels of aid $_{A}$. Evaluated at the median of the sample, our results indicate that the marginal effect of aid $_{A}$ on $f d i$ is 1.18 , and a Wald test confirms it to be significantly positive. Having specified a dynamic model, we can calculate the long run effect of aid $_{A}$ by assuming a that the level of FDI per capita is the same in every period. Evaluating at the median, we find that one additional aid dollar per capita invested in complementary factors draws in $1.97(1.18 / 0.6)$ dollars of FDI per capita in the long run. We conclude from this that aid $_{A}$ generates important short run as well as long run benefits for foreign investors. The results also confirm the crowding out effect of aid invested in physical capital, since one aid dollar per capita invested in physical capital replaces 0.94 dollars of $f d i$, which accumulate to 1.57 dollars in the long run (0.94/0.6).

The effect of population growth is insignificant throughout the analysis. But, contrary to the prediction from our model, we find a positive rather than a negative effect of domestic savings on $f d i$. A plausible explanation is that foreign investors look explicitly at data on national savings when making their investment decisions and interpret a high $s$ as a signal of sustained growth history and good economic prospects. ${ }^{6}$ To adjust for this positive externality we include GDP per capita in column (5). Adjusting for the purchasing power of the population leaves savings insignificant and negative, which suggest that once we correct for the positive signalling effect of a high saving rate, domestic and foreign capital are substitutes as suggested by the theoretical model.

Finally, we perform some tests of hypothesis and present the results at the bottom of the Table. We test the Caselli and Feyrer (2007) conjecture that aid invested in physical capital replaces FDI one for one. The Wald tests show that we cannot reject its validity in most of the cases. We also find that the combined effect of aid $_{A}$ and aid $_{K}$ is significantly positive and between 0.21 and 0.24 (evaluated at the median of the sample), which implies that the substitution effect of aid $_{K}$ is more than outweighed by the positive effects of aid $_{A}$

\footnotetext{
${ }^{6}$ This is in line with evidence showing that the households with the highest lifetime incomes are the ones with highest lifetime saving rates (Carroll, 2000), and that higher growth rates lead to higher savings rates (Carroll, Overland and Weil, 2000; Loayza, Schmidt-Hebbel and Servén, 2000).
} 
on $f d i$ in a typical country. If the marginal effects are evaluated at the mean instead of the median, our conclusions remain the same.

\section{Robustness}

In light of the important policy implications arising from our results, it is necessary to ensure that these results are robust to correcting for possible misspecifications in the empirical relationship between FDI and aid. We carry out three basic checks for robustness of our empirical findings.

\subsection{Technical Assistance}

The grouping of aid variables could be questioned. In particular, aid in this paper does not include Technical Cooperation Grants (TCGs), which contribute to development primarily through education and training. Since TCGs consist of activities involving the supply of human resources or actions targeted on human resources (education, training, and advice) one could easily argue that TCGs would have the same impact as aid invested in complementary factors. In the Appendix (Table 4) we therefore replicate the specifications from Table 1 using an extended definition of aid $_{A}$ that includes also TCGs from the OECD database. Although there is a slight drop in the size of the coefficients, the results from Table 1 carry over.

\subsection{Imperfect Capital Mobility}

If mobility of capital is imperfect, MPK should be allowed to deviate from the gross world interest rate by a risk-premium, $\rho$, that reflects idiosyncratic country characteristics. In this case, the first-order condition in (4) should read

$$
r+\rho=\mathrm{MPK}
$$

and the capital stock in (5) should be redefined accordingly:

$$
k^{*}=\left[\frac{A \alpha}{r+\rho}\right]^{\frac{1}{1-\alpha}} .
$$

While this renders the effect of aid invested in physical capital unchanged, the effect of complementary aid becomes somewhat more complicated. The risk premium impact FDI directly through (18) but, given that

$$
\frac{\partial k^{*}}{\partial a i d_{A}}=\frac{\partial}{\partial a i d_{A}}\left(\left[\frac{A \alpha}{r+\rho}\right]^{\frac{1}{1-\alpha}}\right)=\frac{1}{1-\alpha}\left[\frac{A \alpha}{r+\rho}\right]^{\frac{\alpha}{1-\alpha}} \frac{L \alpha}{r+\rho},
$$


the marginal effect of aid $_{A}$ will also depend on the risk premium and thus on countryspecific characteristics. To capture this econometrically, we include the risk premium level and its interaction with aid $_{A}$, and estimate

$$
\begin{aligned}
f d i_{i t}= & \alpha_{t}+\alpha_{i}+\beta_{0}+\beta_{1} n_{i t}+\beta_{2} S_{i t}+\beta_{3} a i d_{i t}^{K}+\beta_{4} a i d_{i t}^{A}+\beta_{5}\left(a i d_{i t}^{A}\right)^{2} \\
& +\beta_{6} \rho_{i t}+\beta_{7}\left(a i d_{i t}^{A} \times \rho_{i t}\right)+u_{i t} .
\end{aligned}
$$

$\beta_{6}$ and $\beta_{7}$ are expected to be negative because higher risk reduces country $i$ 's attractiveness as an investment location.

To capture the risk premium we include the overall International Country Risk Guide rating as well as its three subcategories of risk: political, financial and economic. ${ }^{7}$ All risk variables are treated as endogenous. In general, lower political risk is associated with higher levels of overall accountability, stability and institutional quality in the political process. In particular, from the ICRG rankings, political risk is lower (1) the higher the government stability, (2) the better the socioeconomic conditions and the investment profile, (3) the lower the number of internal conflicts, external conflicts and political corruption, (4) the lower the military is involved in politics, (5) the lower the religious and the ethnic tensions, (6) the higher the prevalence of law and order, and (7) the larger the degrees of democratic accountability and bureaucratic quality. Results from estimating (20) including these political risk measures are reported in Table $2 .^{8}$

The political risk variable enters only significantly in four cases. Relative absence of external conflict, low level of religious tensions and a high level of democratic accountability suggest all a lower risk premium and tend to attract foreign investors. However, the prevalence of law and order shows a negative impact on FDI inflows (significant only at the $10 \%$ level, though). This counter intuitive result might be due to the fact that we have already accounted for domestic savings, which will be highly correlated with this risk variable: countries characterised by law and order tend to have higher domestic saving.

The interactions between complementary aid and the political risk indicator are more often significant, and the results suggest that government stability, favourable socioeconomic conditions, an attractive investment profile, low military interference in politics and better bureaucratic quality are all supportive of a high steady-state level of capital. Although the results shows a negative impact of the interaction between aid $_{A}$ and the index for low degree of religious tensions, the net marginal effect on FDI remains positive.

Table 3 presents similar estimations taking into account different economic and financial risk measures. The economic risk variables reflect the macroeconomic situation and

\footnotetext{
${ }^{7}$ In order to detect significant effects of aid on FDI, Karakaplan et al. (2005) and Harms and Lutz (2006) use aid interacted with the Kaufmann et al. (2005) governance indicators to capture differences in government effectiveness.

${ }^{8}$ For the results in Table 2, a high value of the different political-risk measures is associated a low overall political risk, and hence, a high value of the different risk measures should have a positive effect on $f d i$.
} 


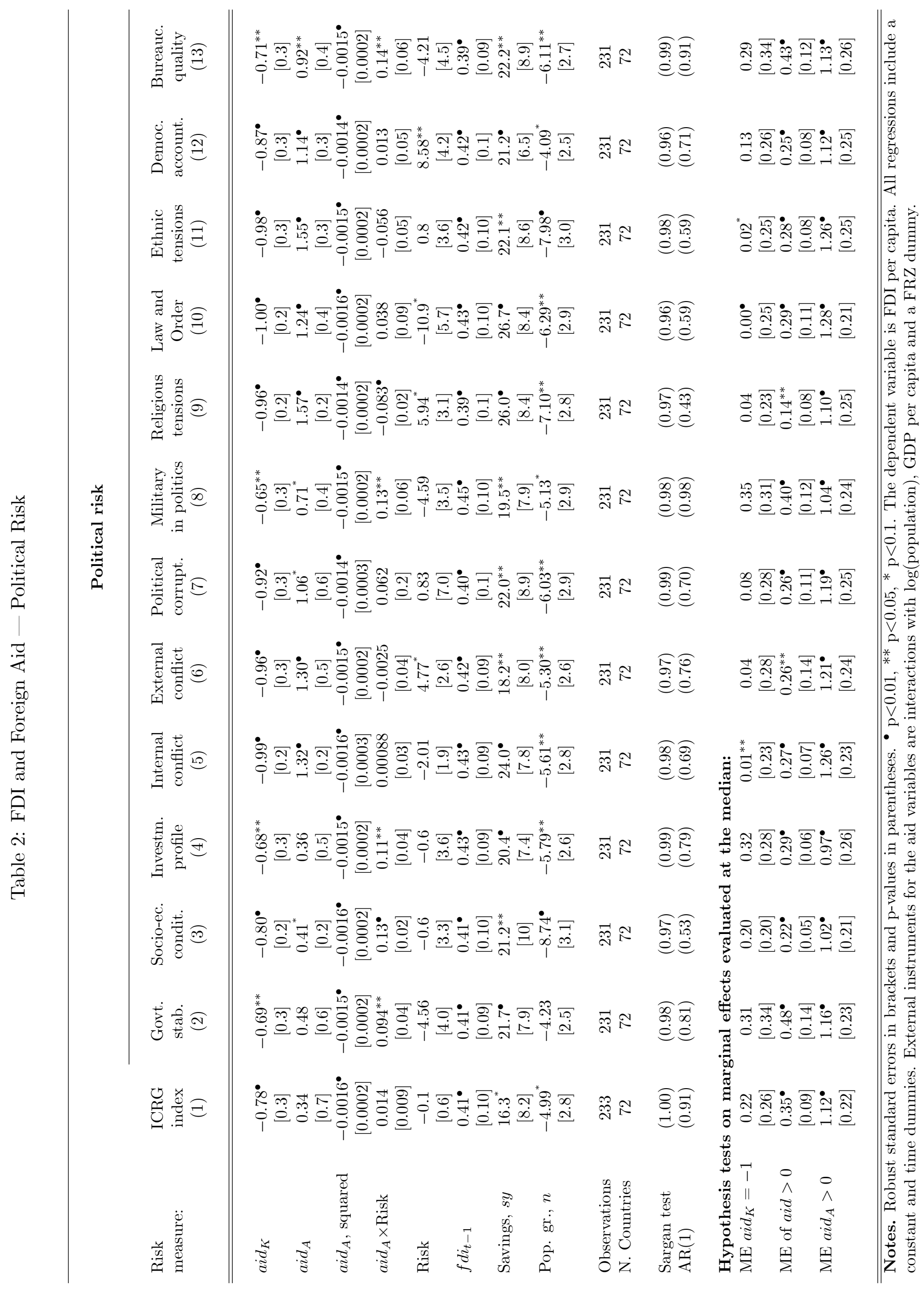




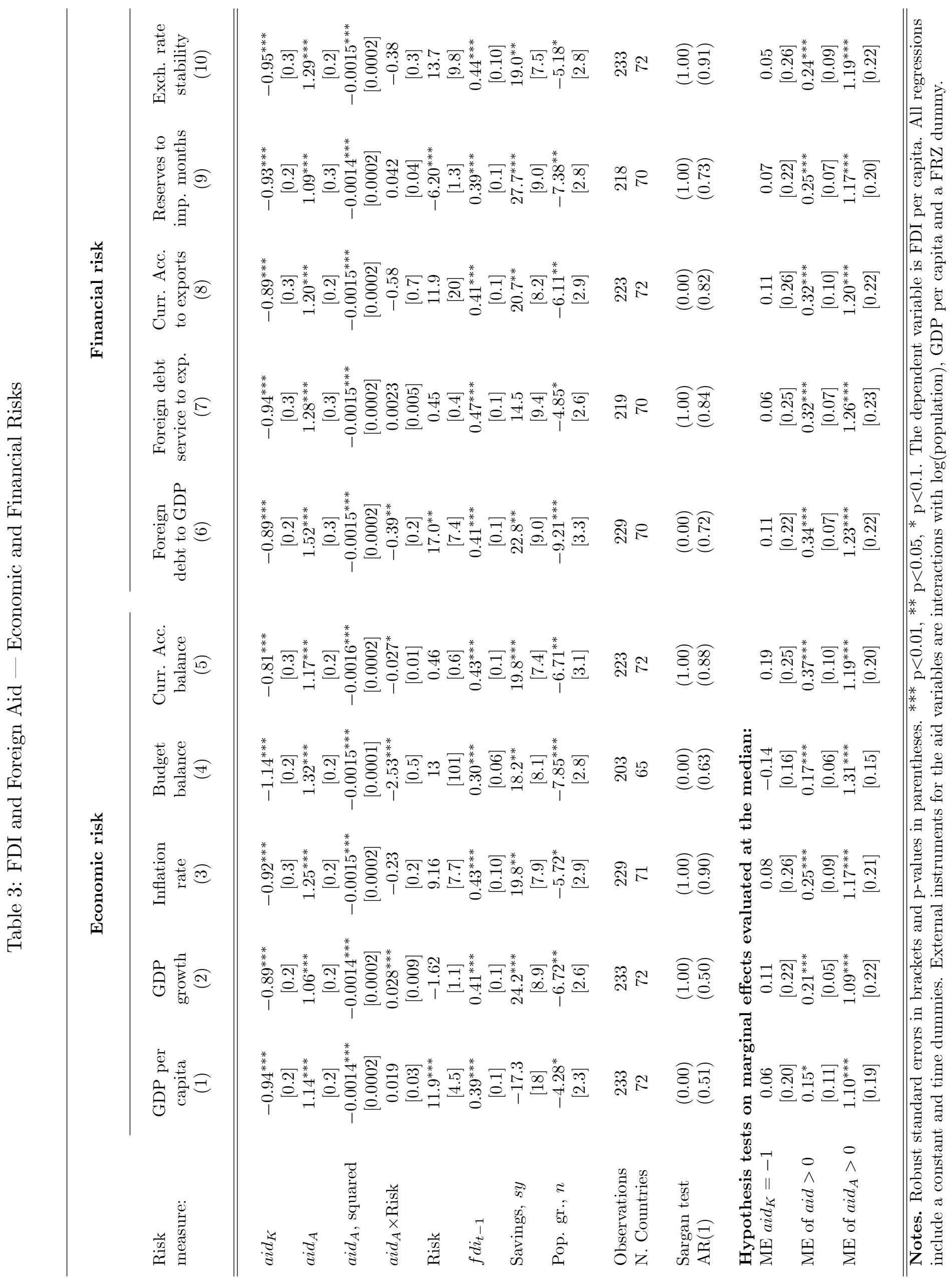


the economic advancement of the host country: GDP per capita, real GDP growth, inflation, the budget balance as a share of GDP and the current account as a share of GDP. The financial risk variables assess a country's ability to finance its official, commercial and trade debt obligations: external debt as a share of GDP, debt service as a share of exports, the current account as a share of export, international liquidity as months of import cover and exchange rate stability (calculated here as the annual change in the real exchange rate). ${ }^{9}$ Results in Table 3 keep our overall conclusions unchanged. It is interesting to note, however, that the political risk variables seem to be more important to foreign investors than the economic and financial risk variables.

\subsection{Omitted Variables}

Tables 2 and 3 show a positive impact from the savings rate on $f d i$. We adjust for this in Tables 5 and 6 including the level of GDP per capita in the regressions. As in Table 1, the effect of savings disappears and it is captured by the level of GDP per capita, which supports our results previously suggesting the existence of positive externalities from $s$ to $f d i$.

However, it is important to notice that once we adjust for the risk of investing abroad by including various proxies for the risk premium, population growth turns out to have a significantly negative impact on $f d i$ in both Tables 2 and 3. One explanation might be that a fast growing population is attractive for the efficiency-seeking investor but that the quality of the abundant labour in some countries might be too poor to attract foreign investors. In this case, a fast growing population might instead cause social tensions and excessive burdens on the public system, which will tend to scare away foreign investors rather than draw in more investments. ${ }^{10}$ We therefore add the primary school enrolment rate from the World Development Indicators (2005) in Tables 5 and 6, to take the quality of the labour force and the level of development into account. ${ }^{11}$ In many cases, the adjustment for the quality of the labour force means that population growth no longer enters significant and in the remaining cases it reduces the size of the initially negative effect on $f d i$. It is interesting noticing that the adjustment for the level of human capital reduces the size of the effect of $a_{i} d_{A}$ on $f d i$. This means that the aid $_{A}$ variable is picking up the information that we intend, and thus substantiates our choice and definition of different types of aid.

\footnotetext{
${ }^{9}$ Similar to the case of the political risk indexes, all these different measures reflect lower overall levels of economic and financial risk.

${ }^{10}$ This is in line with Mankiw, Romer and Weil's (1992) point that a higher population growth rate implies lower per capita human capital levels and thus lower MPK levels. This will have a negative impact on FDI.

${ }^{11}$ The data on school enrolment is highly unbalanced, so we interpolated within countries to fill in gaps, and extended the series with the first and the last values to complete the extremes. The correlation between the original and the transformed series is above 0.98 in both cases.
} 
Finally, while our empirical specification includes both variables predicted by our theoretical model as well as a rich specification of idiosyncratic country characteristics, there might be additional variables that play a role in the allocation choice of foreign investors. To test for this, further regressions included measures of market potential (regional dummies, urban population and rural population), factor market characteristics (size of the labour force, average years of schooling) and market access (openness, number of vehicles, transportation network density, telephone lines and rail lines). None of them turned out significant or to have a qualitative impact on our results. These results are available upon request.

\section{Conclusion}

Due to its potential to transfer knowledge and technology, create jobs, boost overall productivity, and enhance competitiveness and entrepreneurship, attracting FDI to developing countries is essential to contribute to economic growth, development and poverty reduction. Given the emphasis on using ODA as a vehicle for creating a private sector enabling environment, the question of whether or not aid flows induce significantly more FDI inflows becomes an important and relevant question not only on its own right but also as an essential element in the aid effectiveness debate.

The results strongly support the hypotheses that aid invested in inputs complementary to physical capital draws in foreign capital, while aid directly invested in physical capital crowds out private foreign investments. While the impact of the two types of aid together is positive, an important policy implication is that the composition of foreign aid matters and that more aid should be directed towards complementary inputs. Such investments improve the absorption capacity of the recipient country and increase MPK in the host country, which allows it to accumulate more foreign capital without experiencing a drop in domestic investments or a flight of foreign capital.

\section{References}

[1] Arellano, M. and S. Bond (1991), 'Some tests of specification for panel data: Monte Carlo evidence and an application to employment equations', The Review of Economic Studies, vol. 58, pp. 277-97.

[2] Arellano, M. and O. Bover (1995), 'Another look at the Instrumental Variables estimation of Error-components models', Journal of Econometrics, vol. 68, pp. 29-51.

[3] Beladi H. and R. Oladi (2007), 'Does foreign aid impede foreign investment?', Ch. 4 in (S. Lahiri, ed.), Theory and practice of Foreign Aid, Elsevier. 
[4] Blaise, S. (2005), 'On the link between Japanese ODA and FDI in China: A microeconomic evaluation using Conditional Logit analysis', Applied Economics, vol. 37, pp. 51-55.

[5] Blundell, R. and S. Bond (1998), 'Initial conditions and moments restrictions in Dynamic Panel Data models', Journal of Econometrics, vol. 87, pp. 115-43.

[6] Burnside and Dollar (2000), 'Aid, policies and growth', American Economic Review, vol. 90(4), pp. 847-68.

[7] Carroll, C. (2000), 'Why do the rich save so much?', in (Joel B. Slemrod, ed.), Does Atlas shrug?: The economic consequences of taxing the rich, Harvard University Press.

[8] Carroll, C., J. Overland and D. N. Weil (2000), 'Saving and growth with habit formation', American Economic Review, vol. 90(3), pp. 341-55.

[9] Caselli, F. and J. Feyrer (2007), 'The marginal product of capital', Quarterly Journal of Economics, vol. 122(2), pp. 535-68.

[10] Chatterjee, S., P. Giuliano and I. Kaya (2007), 'Where has all the money gone? Foreign aid and the quest for growth', IZA Working Paper No. 2858.

[11] Chatterjee, S., G. Sakoulis and S. J. Turnovsky (2003), 'Unilateral capital transfers, public investment and economic growth', European Economic Review, vol. 47, pp. 1077-1103.

[12] Clarida, R. H. (1993), 'International capital mobility, public investment and economic growth', NBER Working Paper 4506.

[13] Clemens, M., S. Radelet and R. Bhavnani (2004), 'Counting chickens when they hatch: The short-term effect of aid on growth', Working Paper 44, Center for Global Development.

[14] Dalgaard, C. and H. Hansen (2001), 'On aid, growth and good policies', Journal of Development Studies, vol. 37(6), pp. 17-41.

[15] Dalgaard, C., H. Hansen and F. Tarp (2004), 'On the empirics of foreign aid and growth', ECONOMic Journal, vol. 114, pp. 191-216.

[16] Dollar, D. and W. Easterly (1999), 'The search for the key: Aid investment and policies in Africa', Journal of African Economies, vol. 8(4), pp. 546-77.

[17] Hansen, H. and F. Tarp (2001), 'Aid and growth regressions', Journal of Development Economics, vol. 64, pp. 547-70. 
[18] Hansen, H. and F. Tarp (2000), 'Aid effectiveness disputed', Journal of International Development, vol. 12, pp. 375-98.

[19] Harms, P. and M. Lutz (2006), 'Aid, governance and private foreign investment: Some puzzling findings for the 1990s', ECONOMIC JouRnAL, vol. 116, pp. 773-90.

[20] Karakaplan, M. U., B. Neyapti and S. Sayek (2005), 'Aid and foreign investment: International evidence', Departmental Working Paper, Bilkent University.

[21] Kaufmann, D., A. Kraay and M. Mastruzzi (2005), Governance matters IV: Governance indicators for 1996-2004, The World Bank.

[22] Kimura, H. and Y. Todo (2007), 'Is foreign aid a vanguard of FDI? A gravity equation approach', RIETI Discussion Paper Series 07-E-007.

[23] Kosack S. and J. Tobin (2006), 'Funding self-sustaining development: The role of aid, FDI and government in economic success', International Organization, vol. 60, pp. 205-43.

[24] Loayza, N., K. Schmidt-Hebbel and L. Servén (2000), 'What drives private saving across the world?', Review of Economics and Statistics, vol. 82(2), pp. 165-81.

[25] Mankiw, N. G., D. Romer and D. N. Weil (1992), 'A contribution to the empirics of economic growth', Quarterly Journal of Economics, vol. 107(2), pp. 407-37.

[26] Odedokun, M. (2003), 'Analysis of deviations and delays in aid disbursements', Journal of Economic Development, vol. 137(28), pp. 137-69.

[27] OECD (2004), OECD glossary of statistical terms, Organisation for Economic Cooperation and Development.

[28] Reinikka, R. and J. Svensson (2002), 'Coping with poor public capital', Journal of Development Economics, vol. 69, pp. 51-69.

[29] Sørensen, P. B. and H. J. Whitta-Jacobsen (2004), Introducing advanced macroeconomics: Growth and business cycles, MacGraw-Hill.

[30] Thiele, R., P. Nunnenkamp and A. Dreher (2006), 'Sectoral aid priorities: Are donors really doing their best to achieve the Millennium Development Goals?', Kiel Institute for World Economics Working Paper No. 1266.

[31] Turnovsky, S. J. (2000), 'Growth in an open economy: Some recent developments', National Bank of Belgium Working Paper No. 5.

[32] United Nations (2002), Report of the International Conference on Financing for Development, signed in Monterrey, Mexico, 18-22 March 2002. 
Figure 1: FDI and Aid to Physical Capital $\left(\right.$ aid $\left._{K}\right)$

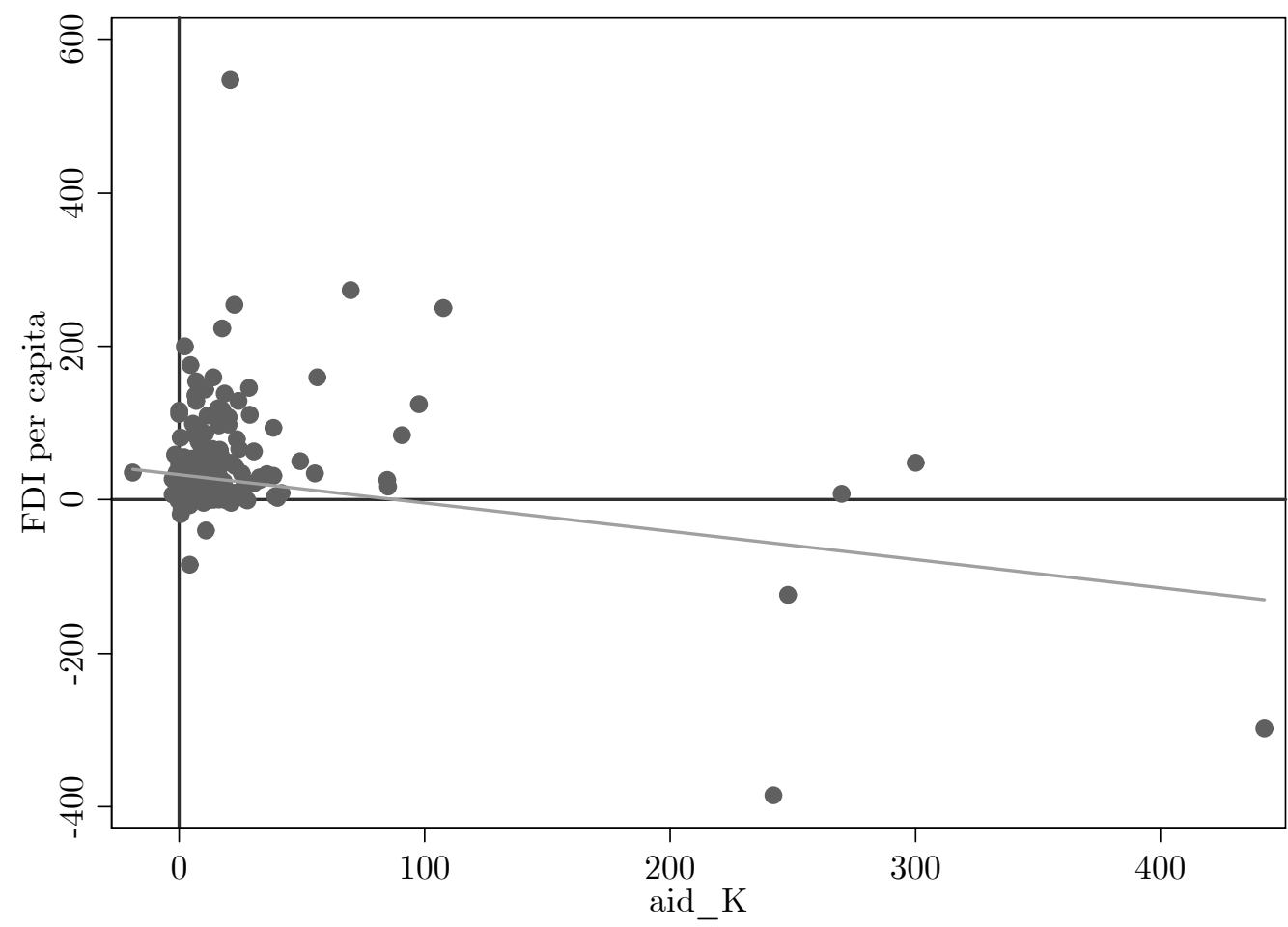

Figure 2: FDI and Aid to Complementary Factors $\left(\right.$ aid $\left._{A}\right)$

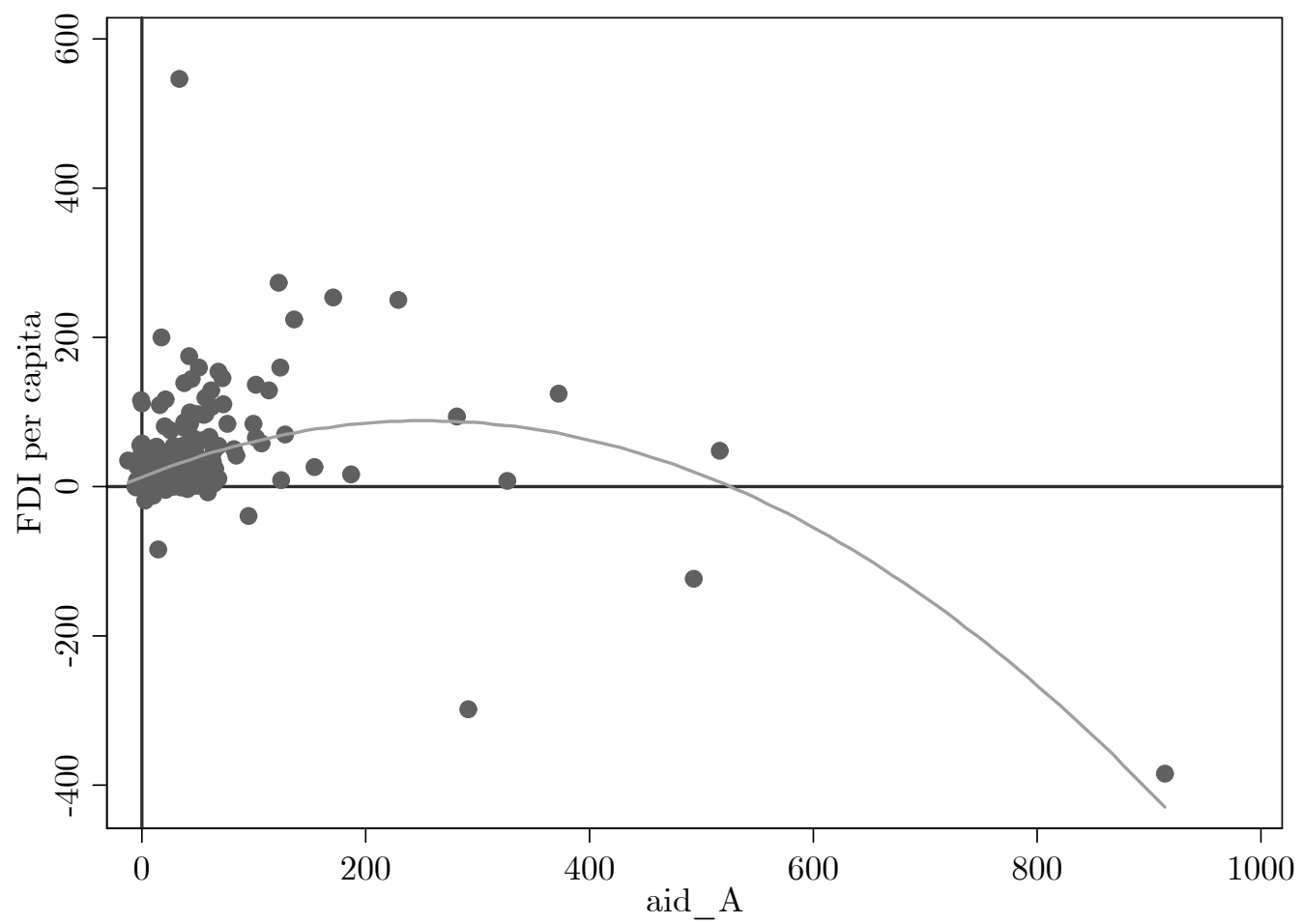


Table 4: FDI and Foreign Aid — Alternative Definition of aid $_{A}$

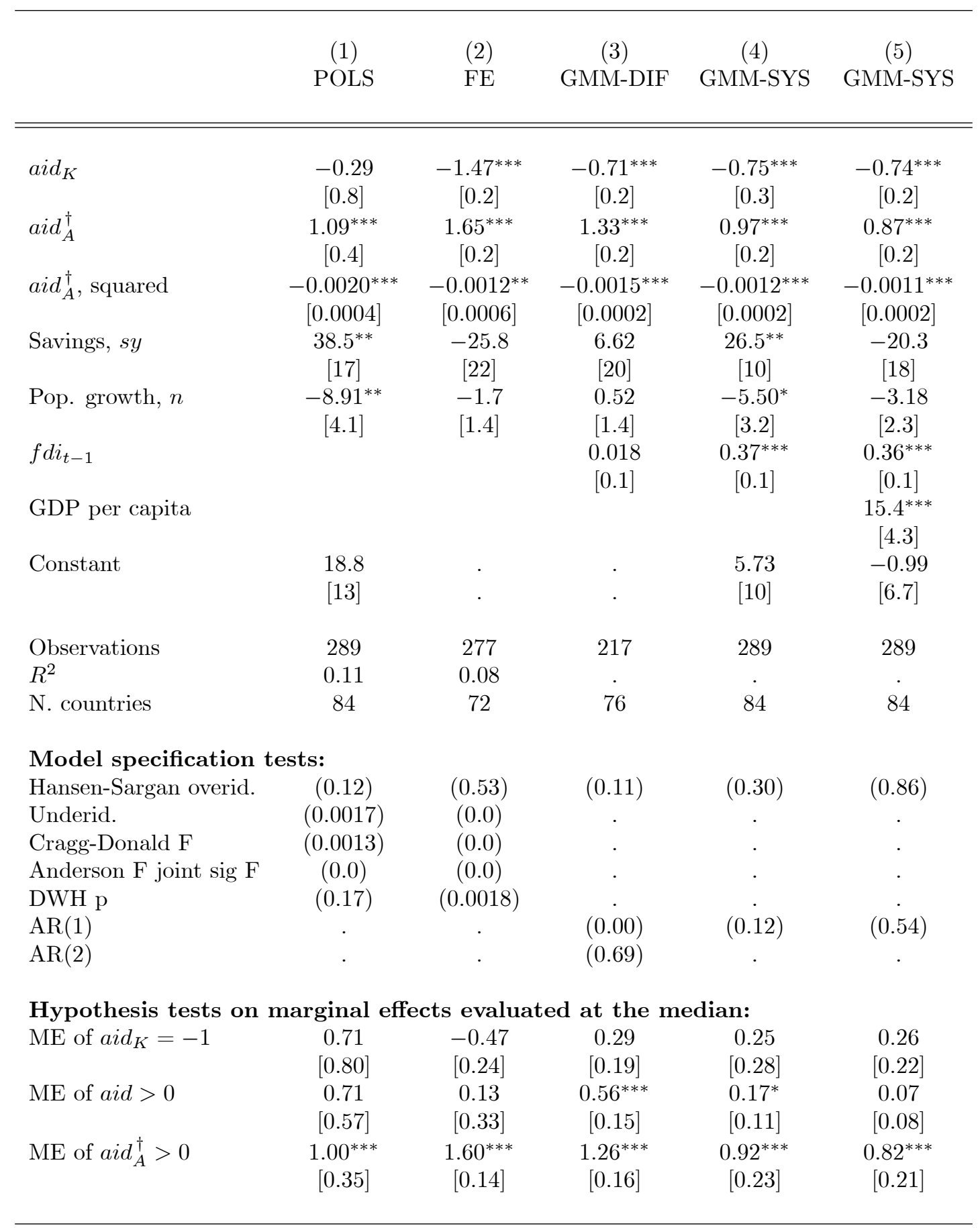

Notes. ${ }^{* * *} \mathrm{p}<0.01,{ }^{* *} \mathrm{p}<0.05,{ }^{*} \mathrm{p}<0.1$. Robust standard errors in brackets, $\mathrm{p}$-values in parentheses. The dependent variable is FDI per capita. All regressions include time dummies. Aid variables are instrumented with own lags, interactions with GDP per capita, $\log \left(\right.$ pop) and a FRZ dummy. $a i d_{A}^{\dagger}$ is defined as aid $_{A}+$ technical cooperation grants. 


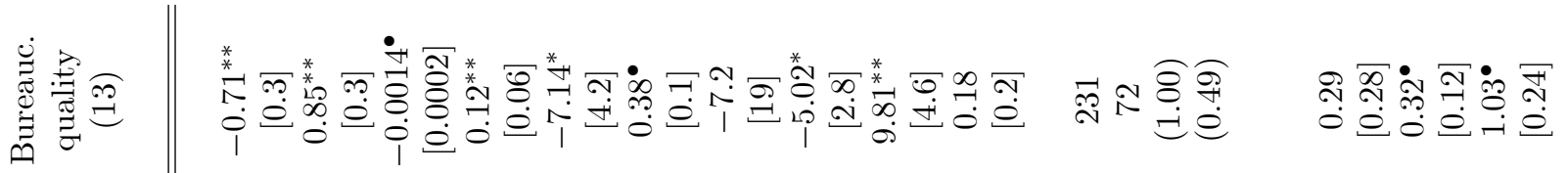

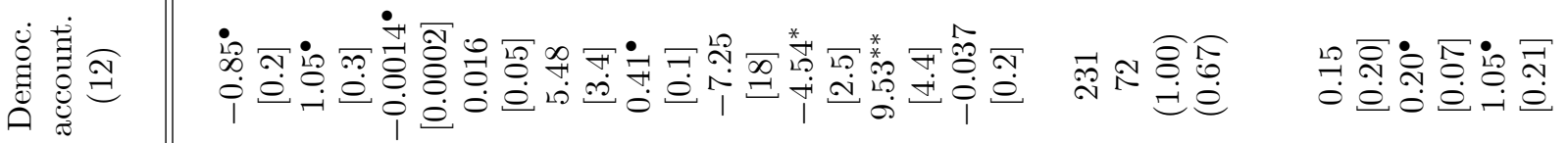

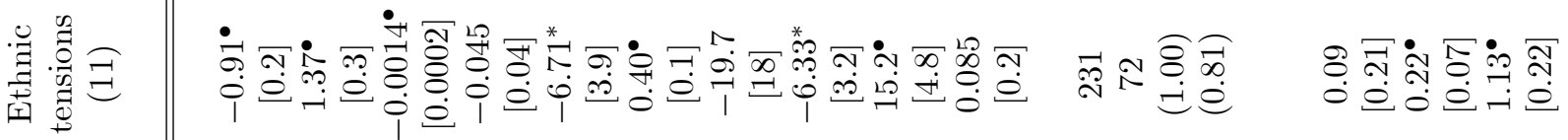

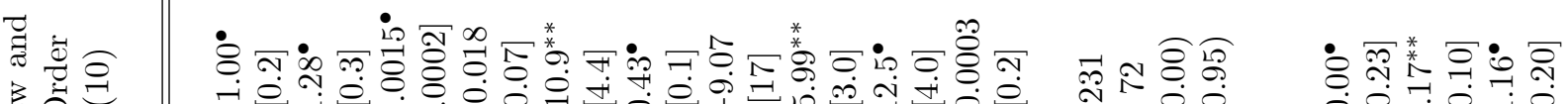

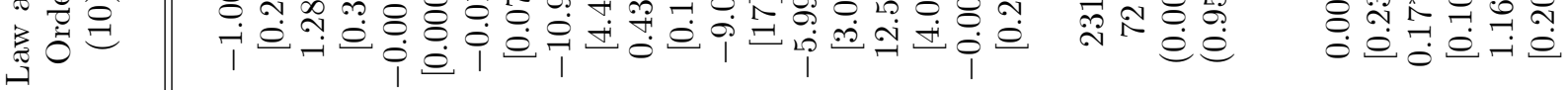

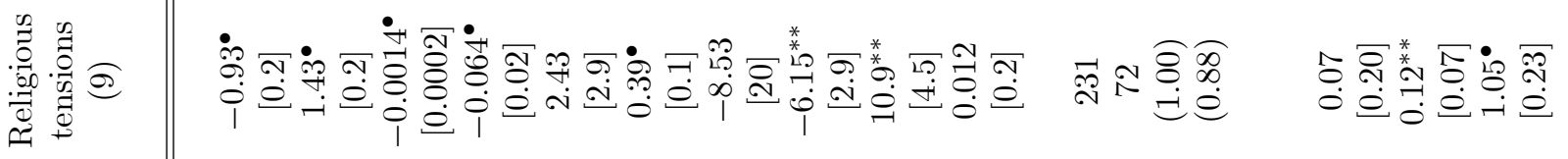

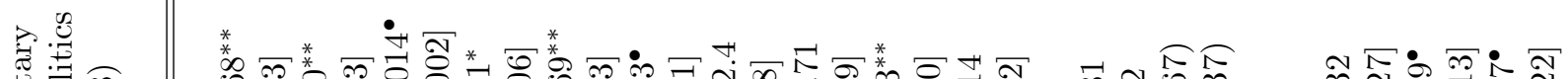

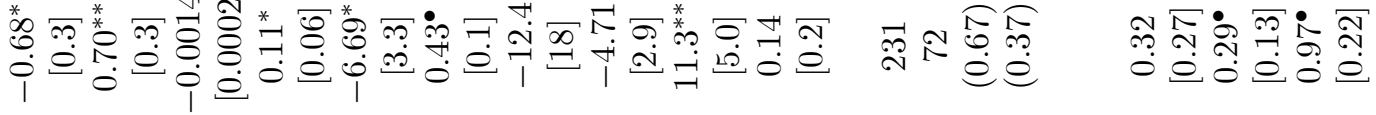
․․

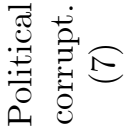

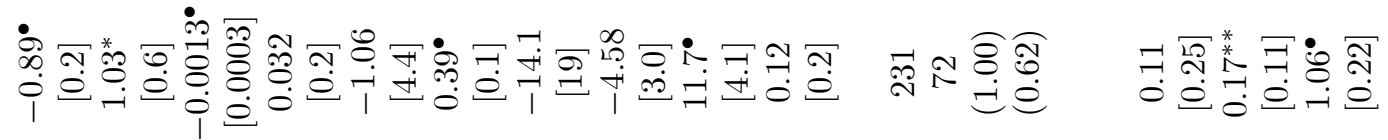

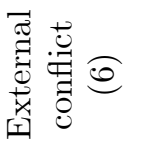

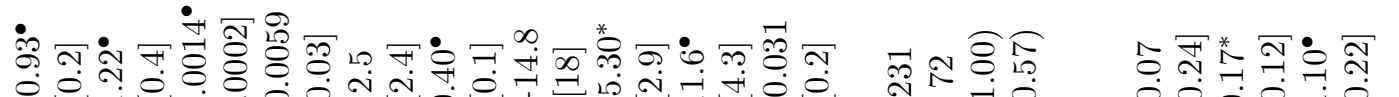
i

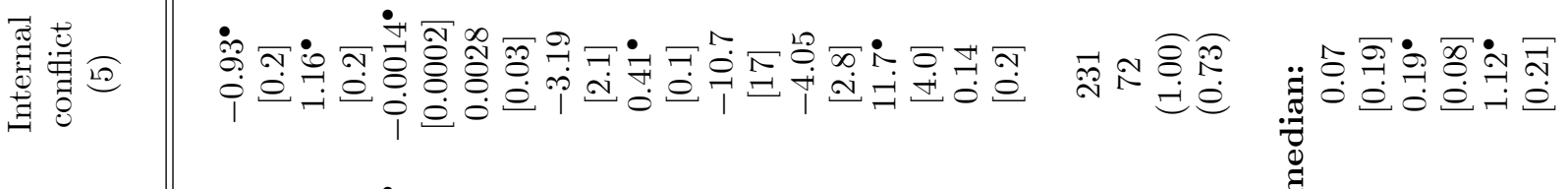

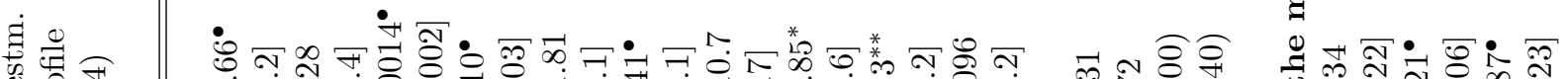
苋苔开 |

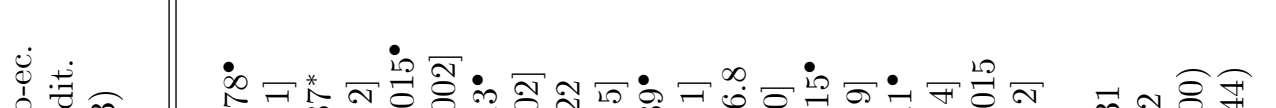
$\checkmark$

递范 |

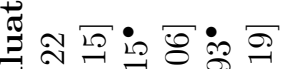

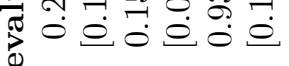

悹密

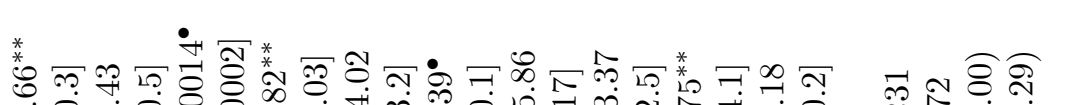
谣

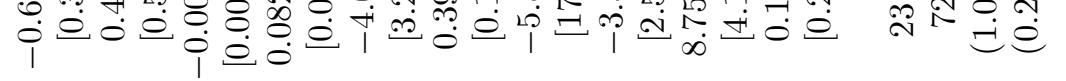

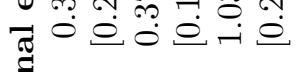

论

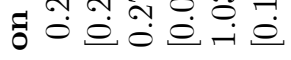
点

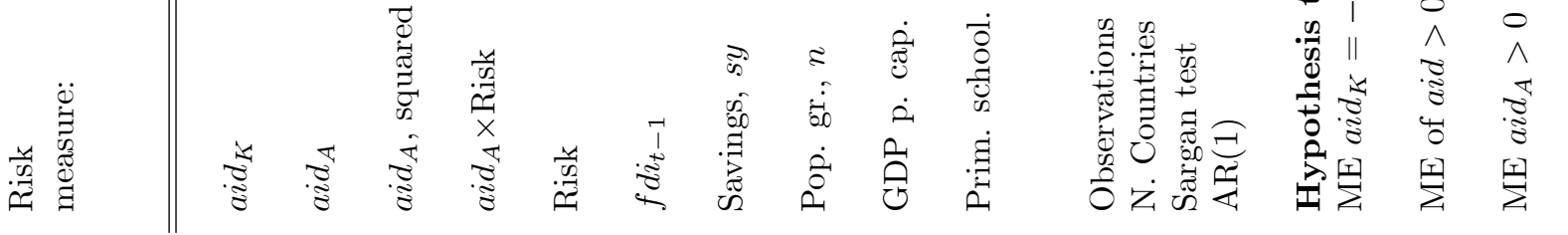




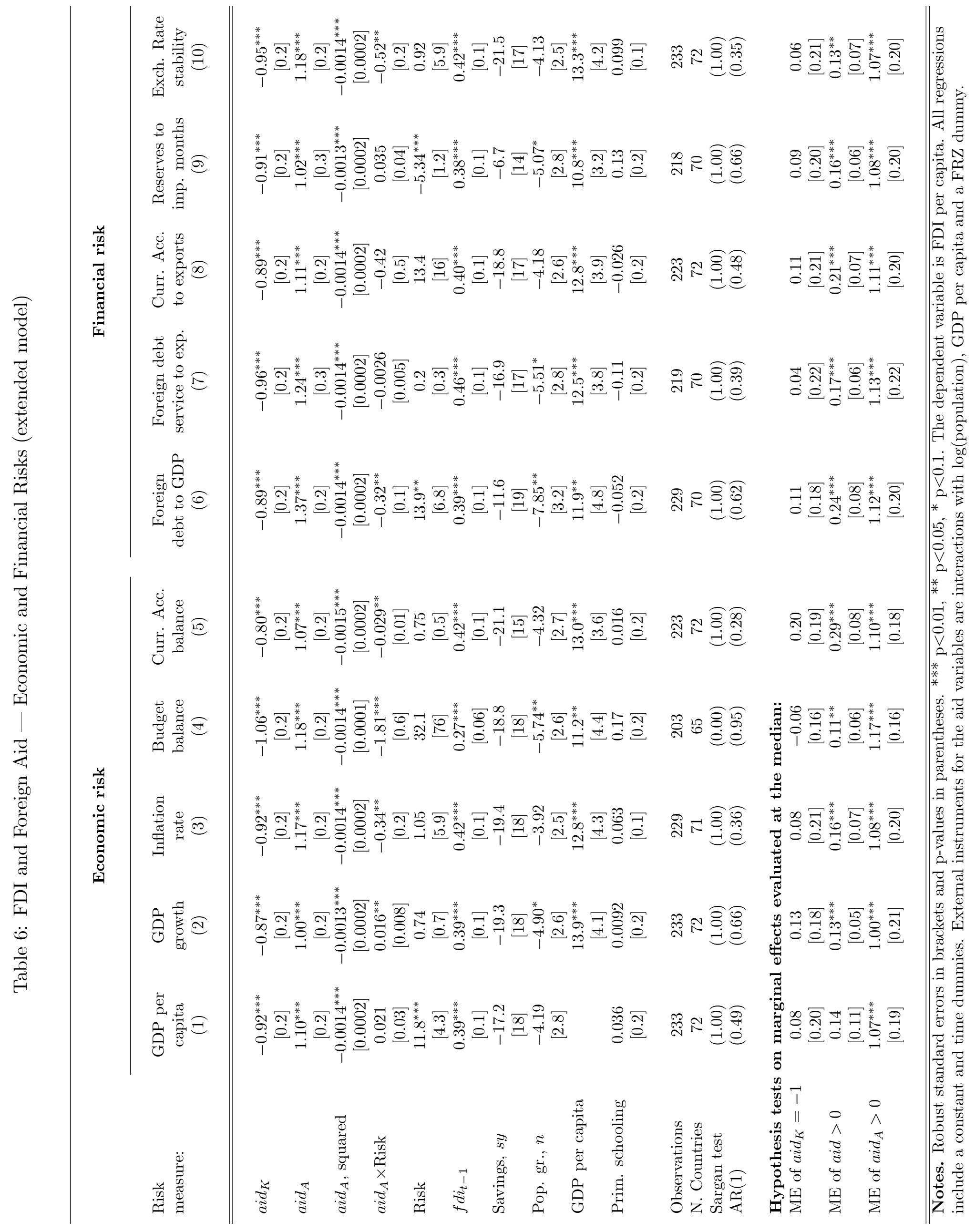


Table 7: Partial Correlations — Main Variables

\begin{tabular}{lcccccc}
\hline & $f d i$ & $\operatorname{aid}_{K}$ & $\operatorname{aid}_{A}$ & $\operatorname{aid}_{A}^{\dagger}$ & $n$ & sy \\
& & & & & & \\
\hline & & & & & & \\
$f d i$ & 1 & & & & & \\
aid $_{K}$ & -0.24 & 1 & & & & \\
aid $_{A}$ & -0.16 & 0.79 & 1 & & & \\
aidd $_{A}^{\dagger}$ & -0.15 & 0.78 & 0.99 & 1 & & \\
$n$ & -0.24 & 0.03 & -0.05 & -0.02 & 1 & \\
sy & 0.35 & 0.12 & 0.19 & 0.17 & -0.18 & 1 \\
& & & & & & \\
\hline
\end{tabular}

Table 8: Partial Correlations — Economic Risk Measures

\begin{tabular}{lccccc}
\hline & $\begin{array}{c}\text { GDP per } \\
\text { capita }\end{array}$ & $\begin{array}{c}\text { GDP } \\
\text { growth }\end{array}$ & $\begin{array}{c}\text { Inflation } \\
\text { rate }\end{array}$ & $\begin{array}{c}\text { Budget } \\
\text { balance }\end{array}$ & $\begin{array}{c}\text { Curr. Acc. } \\
\text { balance }\end{array}$ \\
\hline GDP per capita & 1 & & & & \\
GDP growth & -0.08 & 1 & & & \\
Inflation rate & 0.14 & -0.23 & 1 & & \\
$\begin{array}{l}\text { Budget balance } \\
\text { Curr. Acc. balance }\end{array}$ & 0.12 & 0.18 & -0.20 & 1 & \\
& 0.22 & 0.19 & -0.24 & 0.25 & 1 \\
\hline
\end{tabular}

Table 9: Partial Correlations — Financial Risk Measures

\begin{tabular}{lccccc}
\hline & $\begin{array}{c}\text { Foreign } \\
\text { debt }\end{array}$ & $\begin{array}{c}\text { For. debt } \\
\text { service }\end{array}$ & $\begin{array}{c}\text { Curr. Acc. } \\
\text { to exports }\end{array}$ & $\begin{array}{c}\text { Reserves to } \\
\text { imp. months }\end{array}$ & $\begin{array}{c}\text { Exch. R. } \\
\text { stab. }\end{array}$ \\
\hline Foreign debt & 1 & & & & \\
For. debt service & 0.14 & 1 & & & \\
$\begin{array}{l}\text { Curr. Acc. to exports } \\
\text { Reserves to imp. months }\end{array}$ & -0.56 & -0.17 & 1 & & \\
Exch. R. stab. & 0.30 & 0.28 & -0.22 & -0.01 & 1 \\
& & & & & \\
\hline
\end{tabular}




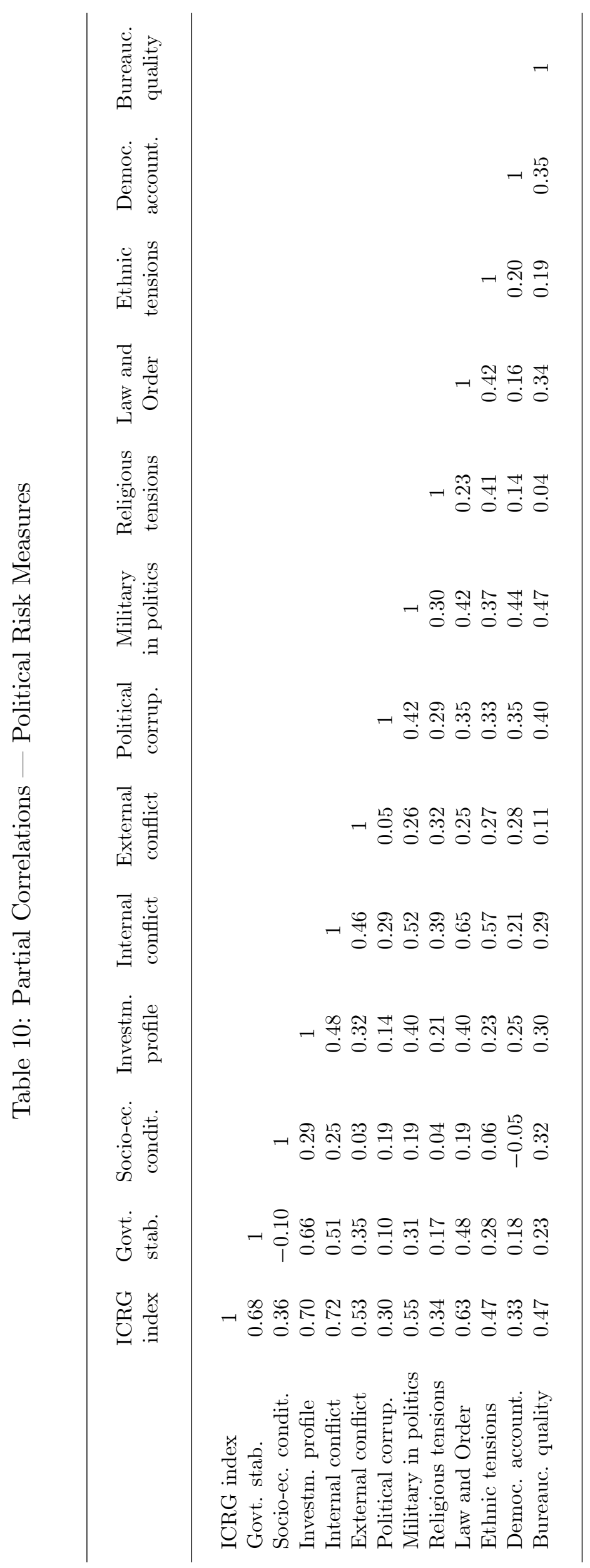


Table 11: Summary Statistics

Obs Median Mean Std. dev. Min. Max

$\begin{array}{lcccccc}\text { Main variables: } & & & & & & \\ f d i & 289 & 9.8 & 27.2 & 64.1 & -384.9 & 547.0 \\ \text { aid }_{K} & 289 & 6.8 & 15.9 & 41.9 & -18.7 & 442.1 \\ \text { aid }_{A} & 289 & 21.6 & 40.1 & 79.6 & -12.2 & 914.4 \\ \text { aid }_{A}^{\dagger} & 287 & 32.5 & 50.3 & 82.2 & -7.0 & 926.0 \\ n & 289 & 2.3 & 2.2 & 1.0 & -5.1 & 7.0 \\ s y & 289 & 0.1 & 0.3 & 0.5 & -0.4 & 3.2\end{array}$

Political risk measures:

$\begin{array}{lcccccc}\text { ICRG index } & 233 & 60.3 & 60.1 & 10.3 & 27.6 & 80.6 \\ \text { Govt. stab. } & 232 & 8.0 & 7.6 & 2.2 & 2.3 & 12.0 \\ \text { Socio-ec. condit. } & 232 & 5.0 & 4.9 & 1.5 & 1 & 9 \\ \text { Investm. profile } & 232 & 6.1 & 6.3 & 1.8 & 1.2 & 11 \\ \text { Internal conflict } & 232 & 8.2 & 7.8 & 2.4 & 0.4 & 12.0 \\ \text { External conflict } & 232 & 9.8 & 9.4 & 2.0 & 2.3 & 12.0 \\ \text { Political corrup. } & 232 & 3.0 & 2.8 & 0.9 & 0 & 5 \\ \text { Military in politics } & 232 & 3.0 & 3.1 & 1.5 & 0 & 6 \\ \text { Religious tensions } & 232 & 5.0 & 4.3 & 1.4 & 0 & 6 \\ \text { Law and Order } & 232 & 3.0 & 3.2 & 1.1 & 1 & 6 \\ \text { Ethnic tensions } & 232 & 4.0 & 3.9 & 1.4 & 0 & 6 \\ \text { Democ. account. } & 232 & 3.3 & 3.3 & 1.2 & 0 & 6 \\ \text { Bureauc. quality } & 232 & 2.0 & 1.7 & 0.9 & 0 & 3.5\end{array}$

Economic risk measures:

\begin{tabular}{|c|c|c|c|c|c|c|}
\hline GDP per capita & 289 & 1.1 & 1.5 & 1.7 & 0.1 & 9.1 \\
\hline GDP growth & 289 & 3.7 & 3.7 & 3.1 & -11.5 & 15.7 \\
\hline Inflation rate & 280 & 0.1 & 0.2 & 0.3 & 0.0 & 2.8 \\
\hline Budget balance & 242 & 0.0 & 0.0 & 0.0 & -0.4 & 0.2 \\
\hline Curr. Acc. balance & 274 & -3.1 & -3.2 & 5.9 & -31.2 & 20.1 \\
\hline \multicolumn{7}{|c|}{ Financial risk measures: } \\
\hline Foreign debt & 285 & 0.6 & 0.7 & 0.6 & 0.1 & 7.0 \\
\hline For. debt service & 270 & 18.8 & 19.7 & 13.5 & 1.3 & 84.5 \\
\hline Curr. Acc. to exports & 274 & -0.1 & -0.2 & 0.3 & -1.6 & 0.4 \\
\hline Reserves to imp. months & 268 & 3.3 & 3.8 & 3.1 & 0.1 & 26.0 \\
\hline Exch. R. stab. & 289 & 0.1 & 0.2 & 0.4 & -1.7 & 2.8 \\
\hline
\end{tabular}




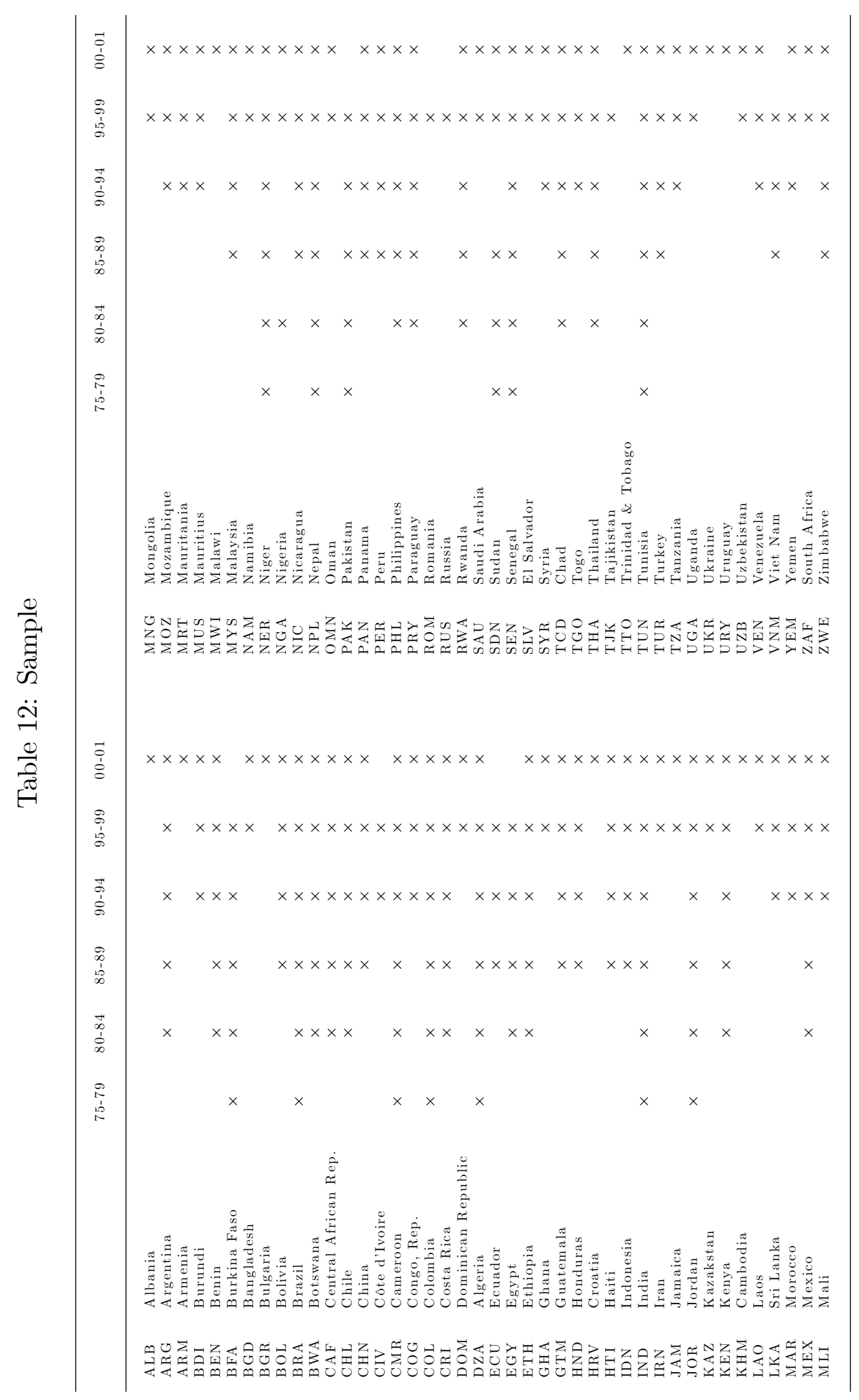

